\title{
Leaf morphoanatomy of four red grapevine cultivars grown under the same terroir
}

\author{
Ana Monteiro ${ }^{1 \mathrm{a}}$, Generosa Teixeira ${ }^{2}$, Cristina Santos $^{3}$ and Carlos M. Lopes ${ }^{2}$ \\ ${ }^{\text {la }}$ Linking Landscape, Environment, Agriculture and Food (LEAF), Instituto Superior de Agronomia, Universidade de \\ Lisboa, Tapada da Ajuda, 1349-017 Lisboa, Portugal. anamonteiro@isa.ulisboa.pt \\ ${ }^{2}$ Centre for Ecology, Evolution and Environmental Changes (CE3C), Faculdade de Farmácia, Universidade de Lisboa, \\ Av. Prof. Gama Pinto, 1649-003, Lisboa, Portugal, gteixeira@ff.ulisboa.pt \\ ${ }^{3}$ IQV Agro Portugal SA, R. Bernardo Sequeira 16, Sala 5, 4715-671 Braga, Portugal, csantos@iqvagro.com
}

\begin{abstract}
This study compare leaf morphoanatomical characteristics of four red cultivars - 'Touriga Nacional', 'Trindadeira', 'Cabernet Sauvignon' and 'Syrah' -, grown side by side at the same terroir. The analyzed leaf traits, under light and scanning electron microscopy, showed large variability among genotypes. 'Trincadeira' has the biggest single leaf area and 'Cabernet Sauvignon' the smallest one. 'Touriga Nacional' showed the lowest leaf dry weight and 'Trincadeira' the highest one, nonetheless there was no significantly differences in leaf dry mass per area and in leaf density. Leaf dry mass per area was positively correlated with leaf density but showed no correlation with leaf thickness. The French genotypes presented higher thickness of the leaf anatomical traits than the two Portuguese ones. 'Trincadeira' showed significantly highest stomata density while the other cultivars showed no significant differences among them. The analyses of the three types of stomata revealed that 'Trincadeira' has the lower percentage of raised above and the highest percentage of sunken stomata while 'Cabernet Sauvignon' showed the opposite behaviour. The hairs on the lower surface presented a similar woolly aspect in all cultivars. The possible role of leaf morphoanatomical characteristics in determining the cultivars adaptation to abiotic stresses is suggested and discussed.
\end{abstract}

\section{Introduction}

Leaf morphoanatomical characteristics are functional and adaptive traits, inherent to genetic factors but also influenced by abiotic ones, which can regulate plant water use, heat dissipation and photosynthesis $[1,2,3,4]$. The capacity of a plant to adjust leaf area to the water availability is also an important trait for drought avoidance. Some authors [5, 6, 7] stated that mesophyll architecture can influence leaf water movement by affecting water flux in the mesophyll and water evaporation at the cell wall surface. Tomás et al. [8] also underline the role of anatomy in mesophyll diffusion conductance and, hence, in the variability of photosynthetic capacity among species. Leaf hairs are also implicated in plant protection from biotic stresses as they can decrease pathogen germination rates by decreasing leaf wet ability [9]. The stomata type and size, width and length, are important traits for plant growth, with small, sunken or sparsely distributed stomata being considered adaptations to minimize transpiration [10].

Regarding the importance of leaf morphoanatomical characteristics for plant resistance to biotic stresses, some authors $[11,12,13,14,15]$ have showed that different Vitis cultivars and even clones presented different susceptibility to downy mildew (Plasmopara viticola (Berck. \& M.A. Curtis) Berl. \& De Toni in Sacc.) and powdery mildew (Erysiphe necator Schwein.). The epidermis is the first barrier for invading pathogens and trichomes can act as mechanical barriers to insects. More studies concerning less susceptible cultivars to biotic stresses are needed to further understand the impact of anatomical traits for example on plant resistance to diseases and pests in order to reduce the enormous pesticide consumption in Viticulture $[16,17]$.

Since microcharacters are less plastic than the macro ones [18], microcharacters could be more important for taxonomical and physiological studies, in particular for 
understanding grapevine cultivars adaptation to different abiotic and biotic stress and, hence, to allow the selection of genotypes better adapted to face the challenges of the climate change expected scenarios for the near future [19].

This study aims to compare the leaf morphoanatomical characteristics of four grapevines red cultivars (Vitis vinifera subsp. vinifera) - the Portuguese 'Touriga Nacional' (TN) and 'Trindadeira' (Tr) vs the French 'Cabernet Sauvignon' (CS) and 'Syrah' (Sy) grown at the same terroir. Despite being major cultivars, little is known about their tolerance to biotic and abiotic stresses. The cultivar TN is known as resistant to diseases and some pests but also as susceptible to water stress and excoriose; $\operatorname{Tr}$ is considered susceptible to downy and powdery mildew and Botrytis bunch rot and also as tolerant to drought stress [20,21,22]; CS is tolerant to diseases (powdery and downy mildews, Botrytis bunch rot) and to water stress but is susceptible to wooden diseases; Sy is susceptible to diseases (powdery and downy mildews, excoriose) and mites and tolerant to water stress (23).

\section{Material and Methods}

\subsection{Plant material and growth conditions}

Leaves of eight-year-old field-grown grapevines of the red cultivars from different geographical origins, the Portuguese 'Touriga Nacional' (TN) and 'Trincadeira' (Tr) and the French cultivars 'Cabernet Sauvignon' (CS) and 'Syrah (Sy), were studied. The 15 years old grapevines were grafted onto the 140 RU rootstock and grown in an rainfed vineyard located at Tapada da Ajuda, Lisbon, Portugal, within the Lisbon Winegrowing Region (38 $42^{\circ}$ ' 27.5' $\mathrm{N}, 9^{\circ} 10^{\prime} 56.3$ ' $\mathrm{W}$ and $62 \mathrm{~m}$ above sea level). The soil is a clay loam with $1.6 \%$ organic matter and a $\mathrm{pH}$ of 7.8. The vines are spaced $1.2 \mathrm{~m}$ within and $2.5 \mathrm{~m}$ between north-south oriented rows and trained on a vertical shoot positioning trellis with two pairs of movable wires, and spur-pruned (18-20 nodes per vine) on a bilateral Royat Cordon system. . Shoots were trimmed once, at berry pea-size. The 1.0 ha vineyard is a varietal collection where the four studied cultivars are planted side by side, ( 6 adjacent rows of $\sim 30$ plants per cultivar) under the same trellis and standard cultivation management. For data collection, four blocks of 10 plants per cultivar were established along a central row. For the macro and microscopic observations twelve fully expanded leaves per block from each cultivar were collected at veraison (end of July), from the $8-9^{\text {th }}$ shoot node.

\subsection{Leaf area, dry mass and leaf density}

For the determination of the single primary leaf area, 12 leaves were scanned at $300 \mathrm{dpi}$ and leaf area was determined from the images using the image processing program Image $\mathrm{B}$. Those 12 leaves were then oven dried at $70{ }^{\circ} \mathrm{C}$ for 48 -h and weighed. From these measurements dry mass per unit area and specific leaf area were calculated. Using leaf thickness data from anatomical measurements, leaf density was calculated as dry mass per unit leaf mesophyll thickness [1].

\subsection{Anatomical measurements}

Five small leaf blade sections were cut from the central part of each fresh leaf, between the primary and secondary veins, and fixed following the usual processes $[24,25]$. The cross-sections $(8-10 \mu \mathrm{m})$ were done using the paraffin histological technique $(26 ; 25)$ at a Minot Leitz 1512 microtome and examined with a Nikon Labophot 2 photomicroscope. Images were captured with a Nikon FX-35W camera equipped with a semiautomatic Nikon PFX adapter (Nikon ${ }^{\circledR}$ ). The light microscopy (LM) observations focused on 22 leaf transverse sections were addressed to thickness of total lamina, mesophyll, palisade tissue, spongy tissues, upper cuticle, upper and lower epidermal cells and stomata dimensions (length and width). For Scanning electron microscopy (SEM) analysis plant material was fixed as above, critical-point dried in a Critical Point Polaron BioRad E3500, and coated with gold in a Jeol JFC-1200. Observations were carried out at $15 \mathrm{kV}$ on a Jeol JSM-5220 LV scanning electron microscope with computer-assisted image analysis. SEM observations focused on the upper and lower epidermis surface details - type of indumentum, epicuticular waxes, stomata density (stomata $\mathrm{mm}^{-2}$ ) and type [27]. All measurements and counts were done on random fields under LM and SEM images, always at comparable leaf situations and magnifications. Quantitative characters are the average of 12 observations for macroscopic parameters.

Statistical analysis were carried out in accordance with the $\mathrm{SAS}^{\circledR}$ program package (SAS Institute, Cary, NC, USA). Before ANOVA, the percent stomata type was transformed using arcsine of the square root of the percentage. Differences between means were assessed by LSD test $(p<0.05)$.

\section{Results}

The average values of the single primary leaf area, dry weight, specific leaf area and leaf density, inserted at the $8-9^{\text {th }}$ node, are presented in Table 1. 'Trincadeira' presented the significantly largest single leaf area and CS showed the smallest leaves while the remaining cultivars returned intermediate values with no significant differences among them. 'Trincadeira' also presented the significantly highest leaf dry weight and TN the lowest one while the French genotypes showed intermediate values. Regarding the specific dry weight and leaf density, no significant differences were observed among genotypes. Specific leaf dry weight showed a significant positive correlation with leaf density $(\mathrm{r}=0.95, p<0.001$, data not shown), but was not correlated with mesophyll thickness $(\mathrm{r}=0.004, p>0.05$, data not shown). In all the studied cultivars the upper epidermis showed polygonal cells with straight walls, epicuticular waxes, some striate 
as well and pearl glands (Fig. 1A). In the lower epidermis the cell organization of all cultivars was similar, with several stomata types (hypostomatous leaves) (Fig. 1B) and one or two types of leaf hairs: i) small, multicellular, erect or slightly curved and ii) very long, probably unicellular, usually flat with a helical rolling, producing a fluffy effect (Fig. 1C, 1D). Both kinds of hairs presented an irregular distribution, no orientation and a variable density over the abaxial epidermal surface within each cultivar. These features and the fluffy long hairs unable the assessment of trichome density.

Considering the leaf cross sections, the studied genotypes showed dorsiventral leaves with an asymmetric mesophyll in structure limited in both upper and lower epidermis by a single layer of flattened cells (Fig. 1E and 1F). The thickness of upper epidermal cells presented the significantly higher values in the cultivars $\mathrm{CS}$, Sy and Tr, and the lowest one in the cultivar TN. Regarding the thickness of the lower epidermal cells, $\mathrm{Tr}$ presented the significantly highest values and CS, Sy and TN the smallest ones (Table 2). The analysis of the upper cuticle thickness showed that the French cultivars presented significantly higher values than TN. Considering the lower cuticle thickness CS showed the significant highest value and $\operatorname{Tr}$ the lowest one (Table 2).

The asymmetric mesophyll was composed of two distinct parts, one close to the upper epidermis and the other one close to the lower epidermis. The palisade parenchyma, consisted of 1 to 3 layers of relatively elongated and close cells. The spongy parenchyma showed small and loosely arranged oval to round cells and irregular intercellular air-spaces (Fig. 1E and 1F). The thickness values of the anatomical traits of total lamina, mesophyll, palisade tissue and spongy tissue showed highly significant differences between cultivars (Table 2). In general the Portuguese cultivars presented the lowest values for all the above mentioned characters and Sy the highest ones. The palisade tissue varied from $40-45 \%$ and the spongy tissue from $55-63 \%$ of total mesophyll.

The stomata density $\left(\mathrm{n}^{\mathrm{o}} \mathrm{mm}^{-2}\right)$ of $\operatorname{Tr}$ was significantly higher than the other three cultivars, which return similar values among them (Fig. 2A). Considering the insertion of stomata in the epidermis, three different types coexisted in all cultivars (Fig. 1B): i) raised above - the guard cells are above and each stomata is flanked by curved subsidiary cells; ii) same level - the guard cells are flattened with the subsidiary cells; and iii) sunken - the guard cells are buried between the subsidiary cells. All the three types of stomata presented a random distribution and an irregular orientation. Significant differences between cultivars were only observed in the raised above and sunken types of stomata (Fig. 2B): Tr presented the significantly highest percentage of sunken stomata (38\%) and CS the lowest one (18\%). Regarding the raised above stomata the higher percentages were presented by CS and TN (36\%). In all the genotypes the dominant type of stomata was the same level stomata which varied from $41 \%$ in $\mathrm{TN}$ and $\mathrm{Tr}$ to $48 \%$ and $52 \%$ of the total stomata in Sy and CS, respectively, although no significant differences were detected (Fig. 2B). When analyzing the dimensions of the three types of stomata no significant differences were observed between cultivars, with the exception of the length of the sunken stomata where $\mathrm{Tr}$ showed the lowest value. In all cultivars the raised above stomata was the type that featured larger dimensions (length and width) whereas the same level stomata were in-between and the sunken stomata presented always the smallest dimensions (Table 3). Idioblasts with calcium oxalate crystals were also seen in leaf cross sections. They were widely distributed in both parenchyma tissues and two different types of calcium oxalate crystals were found inside: raphids and druses.

\section{Discussion}

Leaf size is an important feature regarding water use and heat dissipation with smaller leaves being known to dissipate heat to the ambient more quickly than larger leaves because of a smaller boundary layer resistance (10). As compared with data from similar studies carried out in other Portuguese terroirs $([20,26])$, our results displayed lower single leaf area, showing that the terroir could have a strong influence on leaf size. The observed significant correlation between specific dry weight and leaf density indicate that leaf density was the main responsible for the variation in specific dry weight as reported by Tomás et al. [8]. It is also reported that mesophyll architecture namely leaf thickness and density, which are the two components of leaf dry mass per area, might be related with mesophyll conductance to $\mathrm{CO}_{2}$ [28] and with leaf water movement by affecting water flux in the mesophyll and water evaporation at the cell wall surface $[6,7]$. This pointed out for further studies where ecophysiologic responses need to be correlated with leaf anatomy.

All cultivars displayed upper and lower unistratified epidermal cells with thin walls and a thin cuticle. They had almost the same rectangular or slightly polygonal cell shape. Cuticular striations were seen on both upper and lower surfaces, especially around the stomata and wax deposits were very few or scarce - for example in CS, similar observations were reported by other authors in different terroirs [11, 25]. Martin and Juniper [29] stated that cuticle can provide important information about plant habitat and its response to abiotic stresses. Average cuticular thickness varied between $1.9 \mu \mathrm{m}$ in $\mathrm{Tr}$ to $2.5 \mu \mathrm{m}$ in $\mathrm{CS}$, values that are lower than the ones reported by Monteiro et al. [26]. Since three of the four genotypes used by Monteiro et al. [26], were the same, (TN, Sy and $\mathrm{CS}$ ), these differences might have been determined by the growth conditions, namely the higher drought and heat stress observed in our study. Indeed, under heat stress conditions Ben Salem-Fnayou et al. [30] reported a significant decrease in cuticle thickness in their cultivars, followed by an increase in epidermal cell wall thickness. In our study only the thickness of the upper and lower epidermal cells was measured and for the same genotypes, the values, were higher in Lisbon terroir than in Torres Vedras [26].

In Vitis leaves the stomata are hypostomatous with a stomata density varying with leaf position and growth conditions (50 to 400 stomata $\mathrm{mm}^{-2}$; [31]). In our study 
the obtained stomata density values are within that range but showed a smaller amplitude (from 179 stomata $\mathrm{mm}^{-2}$ in CS to 256 stomata $\mathrm{mm}^{-2}$ in $\mathrm{Tr}$ ). A higher stomatal density is a feature of xerophytic plants as the presence of a huge number of stomata allows more efficient control of leaf gas exchanges [32]. As a rule, the size of stomata is negatively correlated with the number and the size of epidermal cells [33] which is also confirmed in our experiment for all the studied cultivars. The differences observed between the four genotypes on stomata features (density, type and dimensions) might have been an adaptation to the environmental conditions namely for the tolerance to water stress $[10,34]$.

Table 1. Average \pm standard error of single leaf area, specific leaf area and leaf density for the four red cultivars of Vitis vinifera L. subsp. vinifera, cultivated at the Lisbon winegrowing region, Portugal.

\begin{tabular}{lcccc}
\hline Grapevine cultivars & $\begin{array}{c}\text { Single Leaf Area } \\
\left(\mathrm{cm}^{2}\right)\end{array}$ & $\begin{array}{c}\text { Dry Weight } \\
(\mathrm{g})\end{array}$ & $\begin{array}{c}\text { Specific leaf dry mass } \\
\left(\mathrm{mg} \mathrm{cm}^{2}\right)\end{array}$ & $\begin{array}{c}\text { Leaf Density } \\
\left(\mathrm{g} \mathrm{cm}^{-3}\right)\end{array}$ \\
\hline 'Cabernet Sauvignon' & $123.2(9.67) \mathrm{c}$ & $1.24(0.13) \mathrm{bc}$ & $11.2(1.61) \mathrm{a}$ & $0.61(0.10) \mathrm{a}$ \\
'Syrah' & $163.9(11.35) \mathrm{ab}$ & $1.60(0.16) \mathrm{ab}$ & $10.6(1.65) \mathrm{a}$ & $0.54(0.09) \mathrm{a}$ \\
'Touriga Nacional' & $137.8(9.99) \mathrm{bc}$ & $1.21(0.10) \mathrm{c}$ & $9.4(1.10) \mathrm{a}$ & $0.60(0.07) \mathrm{a}$ \\
'Trincadeira' & $174.9(12.87) \mathrm{a}$ & $1.72(0.15) \mathrm{a}$ & $10.6(1.40) \mathrm{a}$ & $0.63(0.08) \mathrm{a}$ \\
In each column different letters indicate significant differences by LSD test at $p<0.05$.
\end{tabular}
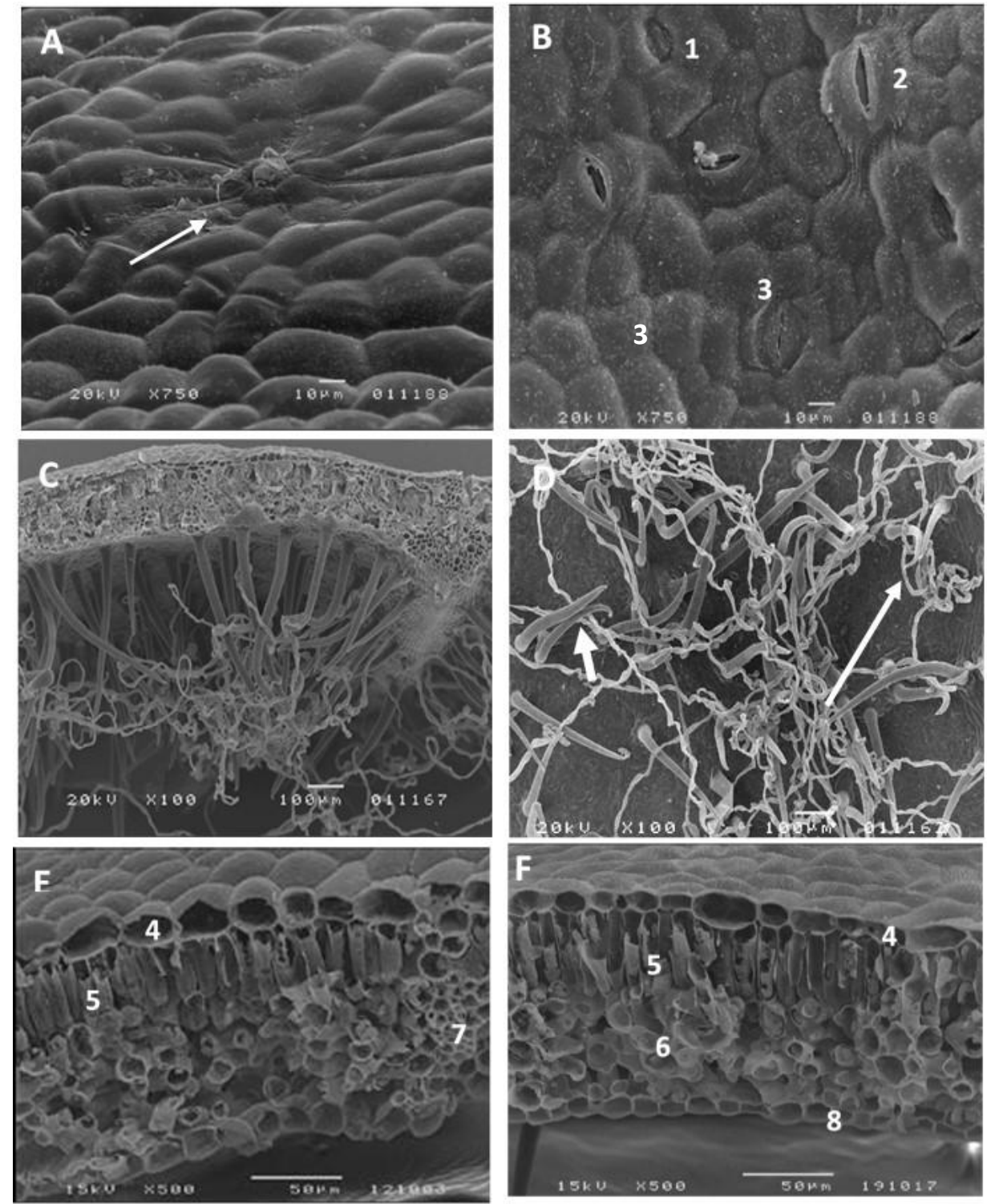

Figure 1. Leaves epidermal tissues and cross sections of Vitis vinifera L. subsp. vinifera red cultivars, upper and lower surface (SEM) - A - 'Cabernet Sauvignon' (x750) upper surface with a pearl gland (arrow); B - 'Trincadeira' (x750) lower surface with the three types of stomata: 1 - sunken; 2 - raised above; 3 - at the same level; C - Leaf cross section of 'Touriga Nacional' (SEM X100). D - 'Trincadeira' (SEM X100) lower surface showing plant hairs of two types slightly curved (small arrow) and long helicoidal (long arrow); E and F - Leaf cross section of 'Cabernet Sauvignon' and 
'Touriga Nacional', respectively (SEM X500): 4 - Upper epidermal cells; 5 - Palisade tissue; 6 - Spongy tissue; 7 Vascular bundle; 8 - Lower epidermal cells.

Table 2. Thickness of leaf anatomical traits (average \pm standard error) of the four red cultivars of Vitis vinifera L. subsp. vinifera, cultivated at the Lisbon winegrowing region.

\begin{tabular}{lrrrr}
\hline Thickness of the & \multicolumn{4}{c}{ Grapevine cultivars } \\
\cline { 2 - 5 } $\begin{array}{l}\text { anatomical character } \\
\mu \mathrm{m})\end{array}$ & 'Cabernet Sauvignon & \multicolumn{1}{c}{ 'Syrah' } & 'Touriga Nacional' & 'Trincadeira' \\
\hline Total lamina & $188.8(5.62) \mathrm{b}$ & $205.9(7.52) \mathrm{a}$ & $162.1(4.77) \mathrm{c}$ & $166.7(1.96) \mathrm{c}$ \\
Mesophyll & $153.2(5.80) \mathrm{b}$ & $171.4(7.17) \mathrm{a}$ & $128.9(3.70) \mathrm{c}$ & $125.2(2.59) \mathrm{c}$ \\
Palisade tissue & $61.1(1.85) \mathrm{b}$ & $71.8(3.38) \mathrm{a}$ & $48.5(1.29) \mathrm{c}$ & $56.5(1.79) \mathrm{b}$ \\
Spongy tissue & $91.9(4.65) \mathrm{ab}$ & $98.7(5.27) \mathrm{a}$ & $81.3(3.23) \mathrm{b}$ & $68.8(2.47) \mathrm{c}$ \\
Upper cuticle & $2.5(0.04) \mathrm{a}$ & $2.4(0.03) \mathrm{a}$ & $2.2(0.09) \mathrm{b}$ & $2.3(0.04) \mathrm{ab}$ \\
Lower cuticle & $2.6(0.16) \mathrm{a}$ & $2.2(0.09) \mathrm{bc}$ & $2.5(0.13) \mathrm{ab}$ & $1.9(0.09) \mathrm{c}$ \\
Upper epidermal cells & $18.3(0.77) \mathrm{a}$ & $18.6(0.60) \mathrm{a}$ & $15.4(0.60) \mathrm{b}$ & $19.5(0.70) \mathrm{a}$ \\
Lower epidermal cells & $18.3(1.34) \mathrm{b}$ & $17.0(0.62) \mathrm{b}$ & $18.3(0.75) \mathrm{b}$ & $21.8(0.78) \mathrm{a}$ \\
\hline
\end{tabular}

In each line different letters indicate significant differences by LSD test at $p<0.05$.

Table 3. Length and width of each stomata type (average \pm standard error) for four red cultivars of Vitis vinifera L. subsp. vinifera cultivated at Lisbon winegrowing region.

\begin{tabular}{lcrrr}
\hline \multirow{2}{*}{$\begin{array}{c}\text { Stomata dimensions } \\
(\mu \mathrm{m})\end{array}$} & \multicolumn{4}{c}{ Grapevine cultivars } \\
\cline { 2 - 5 } & 'Cabernet Sauvignon' & 'Syrah' & 'Touriga Nacional' & 'Trincadeira' \\
\hline Raised above & $37.4(1.11) \mathrm{a}$ & $39.9(0.97) \mathrm{a}$ & $45.4(10.41) \mathrm{a}$ & $37.3(1.02) \mathrm{a}$ \\
Length $(\mu \mathrm{m})$ & $25.4(0.78) \mathrm{a}$ & $28.5(2.19) \mathrm{a}$ & $31.9(8.92) \mathrm{a}$ & $28.9(2.24) \mathrm{a}$ \\
Width $(\mu \mathrm{m})$ & & & & \\
Same level & $28.8(0.65) \mathrm{a}$ & $29.9(0.87) \mathrm{a}$ & $28.5(0.70) \mathrm{a}$ & $29.2(1.03) \mathrm{a}$ \\
Length $(\mu \mathrm{m})$ & $18.5(0.70) \mathrm{a}$ & $18.9(0.89) \mathrm{a}$ & $18.7(0.87) \mathrm{a}$ & $20.5(0.88) \mathrm{a}$ \\
Width $(\mu \mathrm{m})$ & & & & \\
Sunken & $21.6(0.87) \mathrm{ab}$ & $25.3(1.85) \mathrm{a}$ & $24.6(1.04) \mathrm{ab}$ & $21.4(1.01) \mathrm{b}$ \\
Length $(\mu \mathrm{m})$ & $14.1(0.92) \mathrm{a}$ & $15.7(1.40) \mathrm{a}$ & $12.6(0.79) \mathrm{a}$ & $12.8(0.97) \mathrm{a}$ \\
Width $(\mu \mathrm{m})$ & & & &
\end{tabular}

In each line different letters indicate significant differences by LSD test at $p<0.05$
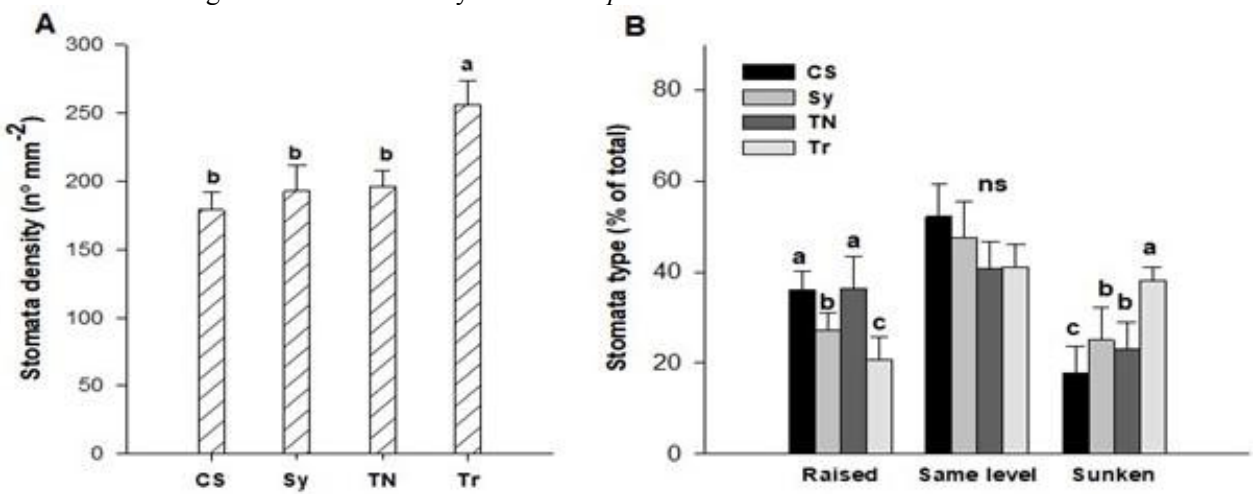

Figure 2. A - Stomata density and B - Percentage of stomata type - raised above, same level and sunken - for the four red cultivars of Vitis vinifera L. subsp. vinifera, cultivated at Lisbon winegrowing region. CS - 'Cabernet Saugivnon'; Sy - 'Syrah'; TN - 'Touriga Nacional'; Tr - 'Trincadeira'. Bars indicate standard error of the mean. Means with same letters are not significantly different $(p<0.05)$ for each cultivar $(\mathrm{A})$ or for each type of stomata $(\mathrm{B})$.

In our study, stomata density varied significantly with genotype, with values of the same order of magnitude as those presented for the same grapevine red cultivars studied by Monteiro et al. [26] at Torres Vedras WR (coastal area $60 \mathrm{~km}$ north from Lisbon) terroir but, with higher values than the ones observed by Costa et al. [20] in Alentejo WR inland south Portugal), where Tr was considered more drought resistant [20,21]. The trichomes density and length varied with grapevine cultivars. A thick layer of trichomes will influence leaf radiation balance and probably will help to reduce water loss by reducing leaf surface temperature and increasing the boundary layer resistance [31]. The leaf hairs observed in the lower epidermis might have implications in epidermal temperature [36b] but not in the tolerance to biotic stresses [14].

The presence of calcium oxalate crystals in the foliar parenchyma can promote a more uniform distribution of light throughout the mesophyll, improving the photosynthetic rate. However, this feature might be related to the plant needs for large amounts of light, since the crystals prisms can increase the light interception and, 
therefore the photosynthetic rate as light will be more evenly distributed around the mesophyll [18]. The crystals can also provide mechanical support and physical and chemical protection against herbivores $[18,35]$.

\section{Conclusions}

The observed significant differences among genotypes in leaf traits suggest a major role of leaf anatomy in determining grapevine capacity for coping to specific environments. In particular, the genotypes which showed small leaves, high leaf density, high stomata density and small and/or sunken stomata may have a comparative advantage in dry and hot regions to support abiotic stresses. The French cultivars revealed most of those xeromorphic leaf anatomical features while the Portuguese ones, in general, tend to present more mesophytic leaf features. Further studies are needed to confirm the suggested association between some of these leaf traits - specific dry weight, leaf density, mesophyll structure and stomata type, for example - and the physiological behavior observed under field conditions.

\section{Acknowledgements}

We would like to thank Telmo Nunes, Faculdade de Ciências da Universidade de Lisboa, for his technical assistance with SEM.

\section{References}

1. Ü Niinemets, New Phytologist 144(1), 35-47 (1999)

2. I. Terashima, YT Hanba, D Tholen, U Niinemets, Pl Physiol, 155, 108-116 (2011)

3. A Palliotti, $\mathrm{S}$ Tombesi, $\mathrm{T}$ Frioni, $\mathrm{F}$ Famiani, O Silvestroni, M Zamboni, S Poni, Funct Plant Biol, 41(6), 634-647 (2014)

4. A Montoro, R López-Urrea, E Fereres, Acta Hortic, 1115, 41-47 (2016).

5. M Gómez-del-Campo, C Ruiz, $\mathrm{P}$ Baeza, JR Lissarrague, J Int Sci Vigne Vin, 37, 131-143 (2003)

6. M Tomás, H Medrano, A Pou, JM Escalona, S Martorell, M Ribas-Carbó, J Flexas, Aust. J Grape. Wine. Res., 18 (2), 164-172 (2012)

7. J Flexas, C Scoffoni, J Gago, L Sack, J. Exp. Bot., 64 (13), 3965-3981 (2013)

8. M Tomás, J Flexas, L Copolovici, J Galmés, L Hallik, H Medrano, M Ribas-Carbó, T Tosens, V Vislap, Ü Niinemets, J Exp Bot 64 (8), 2269-2281 (2013)

9. CA Brewer, WK Smith, Plant Cell Environ. 20, 1-11 (1997)

10. HG Jones, Plants and Microclimate: A Quantitative Approach to Environmental Plant Physiology. Cap. 10, Drought and other abiotic stresses, p. 255-289. (Cambridge University Press, Cambridge, 2014)

11. S Boso, V Allonso-Villaverde, JL Santiago, P Gago, M Durenberber, M Duggelin, Vitis, 49, 43-50 (2010)
12. S Boso, V Allonso-Villaverde, P Gago, BJL Santiago, MC Martínez, Aust J Grape Wine Res, 17, 304-400 (2011a)

13. S Boso, P Gago, V Allonso-Villaverde, JL Santiago, J Mendez, I Pazos, MC Martínez, Sci Hort, 128, 228238 (2011b)

14. S Boso, V Allonso-Villaverde, P Gago, BJL Santiago, MC Martínez, Crop Prot, 63, 26-35 (2014)

15. A Atak, M Akkurt, Z Polat, H Celik, KA Kahraman, DS Akgül, N Özer, G Söylemezoḡlu, G Sire, R Eibach, Ciência Téc Vitiv, 32(1), 23-32 (2017)

16. Eurostat, Eurostat statistics explains http://ec.europa.eu/eurostat/statistics-explained/index. php/Agri-environmental_indicator_consumption_of_ pesticides (2016)

17. I Pertot, T Caffi, V Rossi, L Mugnai, C Hoffmann, MS Grando, C Gary, D Lafond,C Duso, D Thiery, V Mazzoni, G Anfora, Crop Prot, 1-15 (2016)

18. C Metcalfe, L Chalk, Anatomy of Dicotyledons, Vol I. $2^{\text {nd }}$ ed. (Oxford Univ. Press, 1979)

19. IPCC, Climate Change 2013: The Physical Science Basis. Contribution of Working Group I to the Fifth Assessment Report of the Intergovernmental Panel on Climate Change (Cambridge University Press, Cambridge, 2013)

20. JM Costa, MF Ortuño, CM Lopes, MM Chaves, Funct Pl Biol, 39, 179-189 (2012)

21. M Vaz, R Coelho, A Rato, R Samara-Lima, LL Silva, E Campostrini, JB Mota,) Theor Exp Plant Physiol, 28 (2), 205-220 (2016

22. IVV, Lista de castas. (http://www.ivv.gov.pt/np4/111/, 2017)

23. IFV, Catalogue des variétés et clones de vigne cultivés en France. (Institute Français de la Vigne et du Vin, Ministère de l'Agriculture et da la Pêche CTPS, 2ème edition. Montpellier, France, 2007)

24. M Hayat, Principles and techniques of electron microscopy. Biological Applications. 2nd ed. (Ed. Arnold Publ. London. 1981)

25. SE Ruzin, Plant microtechnique and microscopy. (Oxford University Press. 1999)

26. A Monteiro, G Teixeira, CM Lopes, Ciência Tec. Vitiv., 28, 19-28 (2013)

27. C Pratt, Am. J. Enol. Vitic, 25, 131-150 (1974)

28. Ü Niinemets, IJ Wright, JR Evans, J Exp Bot, 60, 2433-2449 (2009)

29. TJ Martin, BE Juniper, The Cuticles of Plants. (Edward Arnold, London, 1970)

30. A Ben Salem-Fnayou, B Bouamama, A Ghorbel, A Mliki, Microsc Res Tech, 74(8), 756-62 (2011)

31. M Keller, The Science of Grapevines. Anatomy and Physiology. (Academic Press, Burlington, MA. 2010)

32. HP Wilkinson, The Plant Surface (Mainly Leaf). Part I: Stomata. In: Anatomy of Dicotyledons. Vol I. 98$117.2^{\text {nd }}$ ed. (Oxford Univ. Press, 1979)

33. T Doheny-Adams, L Hunt, PJ Franks, DJ Beerling, JE Gray, Philos Trans R Soc Lond B Biol Sci, 367 (1588), 547-555 (2012)

34. I Serra, A Strever, P Myburgh, M Schmeisser, PA Deloire, Acta Hort, 1157, 177-181 (2017)

35. P Nakata, Plant Sci, 164, 901-909 (2003) 
36 G Karabourniotis, D Kotsabassidis, Y Manetas, Can J

Bot, 73, 376-383 (1995) 